The Mystery of Return: Agamben and Bloch on St. Paul's Parousia and Messianic Temporality

During the last two decades, a sharp re-reading of St. Paul's letters allowed several thinkers to embed a messianic element in their political philosophy. In these readings, the messianic refusal of the world and its laws is understood through the suspensive act of "subtraction" - a movement of withdrawal which nonetheless too often proved ineffective when translated into political practice.

After analysing Agamben's interpretation of subtraction in terms of "inoperativity", this article focuses on the notion of Parousia as a key element to understanding his anti-utopian account of messianic time. In contrast to Agamben's reading, Bloch's interpretation of the Pauline Parousia envisages the messianic event as infra-historical, but at the same time opened to ultimate (meta-historical) purposes. Bloch's messianic call - I argue - takes the form of mediation, a correction of subtraction towards the direction of a more committed political engagement. I conclude by suggesting that the concrete implementations of this mediation perform their emancipatory function in so far as they assume the character of practical ethics, with the attention directed to the underprivileged and marginalised. 
Since the publication of the seminal work of Richard Horsley and other scholars of the Society of Biblical Literature (Horsley 1997), biblical scholars, historians and philosophers concerned with the relationship between religion and politics - between the sacred and mundane spheres - have paid increasing attention to Paul's letters and to his theology (see Heiden, Kooten, and Cimino 2019; Frick 2013). The recent publications in the series Paul in Critical Contexts, edited by Augsburg Fortress, provide a striking example of the fertility of the critical re-appropriation of Paul through the lenses of power, gender and ideology. But behind this reappearance of Paul as a prominent figure in rethinking the socio-political space, the pioneering work of Dieter Georgi (Georgi 1964) lays as a milestone, as well as the legendary Heidelberg seminar held by Jacob Taubes in late February 1987, shortly before his death (Taubes 2004), drawing on Georgi's concept of "theocracy" as a source of inspiration. Given the impact that this original reading of Paul has had and the extent of its interconnectedness with the classical works of the Western philosophical tradition, it is not surprising that the peculiar "return to religion", which characterised political philosophy at the turn of the century, was imbued with new readings of Paul's letters.

Most of the political thinkers who have paid heed to Paul's theological categories were concerned with the problems of agency and subjectivity that current Marxism has to face, but they posed them from outside the frame of the "twentieth Century form of Marxism: the relationship between party, class and state" (Roberts 2008b, 96). ${ }^{1}$ In these views the messianic, the key concept drawn from Pauline Christology, acquires a central role in redefining the space for socialism today, insofar as it enables a "readiness to force the end", or an ability "to act politically for ultimate purposes" (Walzer 1985, 139). Common to those readings are an atheistic approach, a non-historicist philosophy of history and an emphasis on the evenemental character or precipitousness of the political act, whose specific time can be found in the state of emergency. But the messianic also implies the ultimate attainment of an utterly new world - the Kingdom of God in Pauline terms - and therefore the refusal of this world and of the enforced laws that are ruling it. This transition from the old to the new world, whereby the messianic finds its proper temporal and spatial collocation, ought to be marked - if we follow the readings of e.g. Žižek, Badiou or Agamben - by an act or

1 See for example Žižek (2000) and Badiou (2003); Agamben (2005) discusses the notion of class but only to distance himself from it, consistent with other works (see Agamben 2003). 
movement of subtraction which also informs a correspondent political vision.

The category of subtraction was firstly envisaged by Badiou, aiming to escape the suffocating grip of the state (Hallward 2003, 98), perceived as the "objective and violent core of legal domination" (Hallward 2003, 98). Subtraction finds its place, according to Badiou, between two other modes of negation of the current socio-political-economic structure, destruction and communication (Hallward 2003, 272). The first refers to the disintegration of an old world - the bourgeois state - via a violent and frontal opposition to it: in short, to class struggle possibly bursting into a revolution; the second, on the contrary, is an attempt at negating the current framework without its annihilation and takes the forms of the democratic opposition to which we have become accustomed (Badiou 2007). While the first movement entails the risk of slipping into an authoritarian form of the exertion of power - personified by Stalin's dictatorship - (Hallward 2003, 273) the second results in a fictitious opposition that never achieves the aimed goal: the outcome is a death of negation and political hope, which leads to despair (Badiou 2007). An alternative and not (only) destructive form of negation has to be sought in the indifference to past laws, in the suspension of the political structure, namely: in subtracting the subject from the framework of a normal state (Badiou 2007). If we maintain that the reality of the socio-economic-political structure ultimately lays on the categorial distinctions that build up logical norms and substantial predicates, the act of subtraction consists, in the first instance, in a withdrawal from reality and in appeal to the real that does not find any suitable representation there. In other words, this movement is the "infinite subtraction from the subsumption of the multiple beneath the One of the concept" (Badiou 2004, 108). Through a break with the objective structures namely from social and historical particularities - subtraction acts as a subjective gesture performed as a non-consensual "politics of truth" reviving ideas of justice and equality (Chattopadhyay 2011). This movement of disentanglement from legal, gender, ethnic, class, etc. identities produces the generic, disregarding all predicates and therefore producing the universal. ${ }^{2}$ As the act of subtraction must be "devoid of any aim that would be representable in the object or supported by a principle of objectivity" (Badiou 2004, 112), it can be described, mutatis mutandis, as an attempt at thinking a form of being deprived of the Aristotelian entelechy.

2 It is here worth noticing the affinity of the generic with the quodlibet, the in-essential subject of Agamben's coming community (Agamben 2003). 


\section{Practices of passive}

resistance, strikes,

squatting, etc. are among the most common translations of the

act of subtraction to

the field of political

action but have not

proved successful in

curbing the hegemony

of the capitalist eco-

nomy and the state as

its counterpart.
The transfer of this movement from the theoretical elaboration to the sphere of action implies in fact the imperative of a refusal to interact with any structure that entails a political identity without necessarily obliterating it, but rather suspending or eluding it. Practices of passive resistance, strikes, squatting, etc. are among the most common translations of the act of subtraction to the field of political action but have not proved successful in curbing the hegemony of the capitalist economy and the state as its counterpart.

The eventual ineffectiveness of such practices leads to questioning the emancipatory potential of the subtractive interpretation of the messianic. In analysing Žižek's, Badiou's and Agamben's interpretations, John Roberts raises the problematic status of their account of messianic time and its engendered political implications:

\footnotetext{
The subtractive, renunciative, and suspensive conditions of the political subject are the necessary (but not sufficient) conditions for clearing a distance between what might be named as revolutionary politics and the day-to-day "democratic" representation of politics under mature capitalism. (Roberts 2008b, 101)
}

The exodus from identity politics in the attempt to re-build an opposition to the current economic-political structures is what Roberts refers to when he talks about the "subtractive, renunciative, and suspensive conditions of the political subject", acknowledging the ineffectiveness of their corresponding practices. This limit raises the following question - which seems to have become even more pressing in the last few years: if the politics of subtraction is only the necessary condition, what would be sufficient to endow the political subject with the capacity to erode capitalism's dominance and overturn its power?

To answer this question, this paper will discuss one account of political subtraction, namely Giorgio Agamben's "inoperativity", as presented in his text The Time That Remains via the reading of the Pauline concept of Parousia. This theoretical approach to politics will be linked to the messianic conception of time as expounded in the same text, pointing out the weak and passive forms of political (in)activity entailed in this framework. This paper will then move from the interpretation of the same figure contained in the Pauline letters - the Parousia - proposed by Ernst Bloch, showing the eschatological afflatus in his messianic temporality. Bloch's framework enables on the one hand to avoid any imposition of identity on the political subject, and on the other to engage with the real in terms of "mediation", where the ultimate goal is envisioned as acting in the historical hic et nunc. The paper will finally 
suggest that the Blochian peculiar future-oriented temporality - eventually lying on his ontology of not-yet being - is one of the places where the sufficient condition to address the current impelling political demands of the underprivileged and the marginalised can be sought.

\section{Inoperativity, or Agamben's subtractive politics}

The concept of inoperativity (inoperosità) is central to Agamben's entire work and arguably the core of his entire production from Homo Sacer on. In fact, the philosopher reaches the point of equating the political sphere to inoperativity tout court: "Politics is that which corresponds to the essential inoperativity (inoperosità) of humankind, to the radical being-without-work of human communities" (Agamben 2000b, 14142). Agamben, moving from a Foucauldian perspective, maintains that biopolitical apparatuses (states, nations, etc.) exert their power directly on the living body of the subjected individuals, not only setting their tasks but also disciplining their acts by forcibly directing them towards predetermined goals. This control over the bodies takes place, for Agamben, in the form of steering them as a means to an end, thus denying the very essence of humankind, namely the absence of a determinate essence. By severing the co-opting linkage between potentiality and actuality, by negating a plain transitus de potentia ad actus (Agamben 1998, 62), Agamben seeks to restore man to the dimension of pure potentiality, that is, the free choice to be or not to be in a determinate status. This freedom, however, takes place not so much qua the possibility to pass into actuality as the possibility of his own impossibility: the capacity not to do something, not to fulfil his assigned task, not to be a determinate being. This capability, inherent to human beings, is thus properly restored in an act of subtraction, which Agamben names inoperativity and which constitutes the political act par excellence. As Prozorov notes:

For Agamben, the way to bring things to the end consists neither in the teleological fulfilment of a process of development (the end as completion or accomplishment) nor in the merely negative act of the destruction or elimination of an object (the end as completion or accomplishment) [...]. Instead, it is the process of becoming or rendering something inoperative, deactivating its functioning in the apparatus and making it available for free use. Happy life is thus made possible by neutralizing the multiple apparatuses of power to which we are subjected, including our own identities formed within them. (Prozorov 2014, 31) 
The negation of the identitarian construction of the political subject, together with the deactivation of the apparatuses which seize its living body, are the two dynamics which subtract men from the control over their life and re-enable a free use of the body itself, no longer forced to accomplish a given task. Prozorov suggests (Prozorov 2014, 33) that this act of subtraction might find its counterpart in the political praxis of the Italian Autonomist Marxist movement in the late 1970s. However, it would be more accurate to refer, as Stefano Franchi does, to the theorisations of Mario Tronti, which during the 1960s laid the background for "workerism" and provided the theoretical ideas for the subsequent autonomist movements. Workerists claimed that since

capital is essentially a social power that requires, as a prerequisite, the existence of productive labor [...] a withdrawal from labor, or more generally, a refusal to collaborate with capital in the organization of labor by presenting, for instance, demands that cannot be satisfied, is a political "act" of destruction that would bring down the capitalist organization of society. Politics becomes passive in the sense that canonical form of Marxist political action, the workers" struggle against capital, is identified with a denial of any action at all, as Mario Tronti declared in "The Strategy of refusal". (Franchi 2004, 38; see Tronti 2019)

Behind these ideas there was a series of practices of insubordination and sabotage which spread and radicalised in factories, until their explosion in the autumn of 1969: the rejection of work was conceived as a unifying practice of struggle as it implemented a refusal of the obligation to produce surplus value. Proletarian expropriations, self-reductions of bills and rents, and squatting, were among the practices gravitating around the concept of the refusal to work. As Franchi points out, a "thematic affinity" between the workerist framework and Agamben's inoperativity is somewhat striking, since Agamben reaches similar conclusions from a philosophical standpoint almost entirely alien to the Marxist conceptual system (Franchi 2004, 38).

The capacity not to work, to refuse any allegiance with the biopolitical machine, depends not so much on the disregard for the assigned end as on the intrinsic absence of any end itself. Human beings are, for Agamben, inherently devoid of any determinate identity, and there is therefore no telos in their life apart from that which has been imposed upon them by the apparatuses of power. As a consequence, inextricably bound up with the essential inoperativity of human beings, there must be a conception of time deprived of any orientation to a future goal namely, an anti-teleological conception of time. Were human activity 
directed to an end - even the utopian end of liberating humanity from the constraints of the biopolitical power -, a person's acts would be helplessly trapped in the net of teleology and so eventually of identity politics. The exclusion of any utopian projection into the future from Agamben's political philosophy has been well described by Carlo Salzani:

Radical politics is usually based on imagining that something very different from his world is possible and that the possibilities of this new world lie in the future. To start all over, though, implies a de-cision, the drawing of lines and demarcations between the old and the new, the past and the future, and the violence that goes with it. For Agamben, to the contrary, it is in this world, in the present, that we have to uncover the potentialities for the new world, a supplementary world that exists already, in potential. [...] And this implies rendering inoperative [...] all historical and utopian projects. Redemption is not opera, work, but, rather, a peculiar sort of sabbatical vacation from all the communities of the future, from everything about the future that demands a production, from all the demands of the future. (Salzani 2012, 227)

Agamben's political thought is then characterised by the sheer absence of any new world, of any utopia which has just not yet been fulfilled. It is rather to the present - devoid of any assigned new telos - that political thought and action are directed. However, conceiving a political philosophy denuded of any future end does not entail the lack of a reference to the past, which on the contrary plays a crucial role. In this regard - as well as with respect to the critique of violence (see Liska 2009) Agamben follows the lead of Benjamin appropriating some of the key concepts of the Benjaminian philosophy of history and messianic time (see Hegarty 2010, 25). Although a thorough analysis of the relation between the two thinkers lies beyond the scope of this paper, it is worth mentioning Agamben's arguably most relevant source in terms of furnishing a background for understanding his messianic conception of time. Only after having done that will we discuss the link between inoperativity and messianic time.

\section{Agamben: Parousia as Presence}

Walter Benjamin is without doubt one of the main thinkers of the last century who tried to locate politics in fidelity to the messianic event (Martel 2011; Khatib 2013). Inheriting Benjamin's capacity to shift between a variety of fields and disciplines (see Borsò et al. 2010), Agam- 
ben has more than any other who has contributed to the recent Pauline revival explicitly followed Benjamin's lead. However, the reference to some of the key texts of the latter shows a re-elaboration of Benjamin's accounts of messianism and history, which are twisted in the direction of inoperativity.

In his book on the apostle, Agamben traces three parallels between Paul and Benjamin making the latter almost an heir of the Pauline bequest. The first similarity is to be found in the second thesis on history (Benjamin 2010). Agamben tracks down what seems to be a hidden citation: Benjamin affirms that a weak messianic force (eine schwache messianische Kraft) has been given to us - and this closely resembles Paul affirming that his power is fulfilled in his weakness - and in Luther's translation we find both the words "schwache" and "Kraft". ${ }^{3}$ This weak messianic power is for Agamben the quintessence of the politics of subtraction or inoperativity, which finds its proper time in the moment of the Jetzt-Zeit, the famous concept developed by Benjamin. The second parallel is that between the Jetzt-Zeit and the Pauline insistence on ho nyn kairós, the time of now, which designates messianic time. This is the instant when a cut in the continuum is made and a disconnection from the homogenous fabric of time is established. The third parallel is finally to be found in the concept of image: in Paul the great moments of the past are collected and summarized in a typos - in Luther: Bild - which creates the relation between those moments and the present messianic time. In Benjamin the convergence of past and present happens precisely in an image which dialectically determines a constellation (see Benjamin 1999, 463; Benjamin 1998, 29).

These three aspects of Benjamin's notion of messianic time structure Agamben's Pauline political theology in so far as they help him in shaping the relation between inoperativity and present time. There is no doubt that weakness is central to Benjamin's messianism as well but, as Werner Hamacher has explained, here it takes on two different meanings. Firstly, since the "weak messianic force" has been "endowed" to us (Benjamin $2007,254)$, this force "is not one that is our own [...] something that we have at disposal by our own means, [...] it is not an ability that springs from ourselves" (Hamacher 2001, 165). Secondly, "it has to become extinguished in each future in which it is not perceived or actualised" (Hamacher 2001, 165): this force has to be grasped in the

3 It has been noted that the stress on the weakness of the messianic force could well be linked more to Hermann Cohen than to Paul himself (Deuber-Mankowsky 2008). 
time of now or else it vanishes - and weakness is its most important trait as it indicates "the susceptibility, on principle, to its failure" (Hamacher 2001, 168). Agamben appropriates the Benjaminian framework - which entails a linkage between a past generation that has granted to the present one this messianic force - thus adopting the bond of messianic time and weak messianic force, but reads this weakness as the intrinsic absence of telos in any human act. In this way, he connects inoperativity (the only possible character of mankind that keeps it open to possibility) to the messianic "time that remains" (the only time at our disposal). It has to be noted, however, that while in Benjamin the "secret agreement between the past and the present one" is expressed in the wait for redemption - an irruption into human history, which catastrophically poses an end to it - in Agamben this is turned into forms of suspensive political practices that are already implementable. In this alteration of the Benjaminian weak messianic force, this latter belongs to the present generation: it only needs to be put into practice by deactivating the machine, by erasing any reference to a future happy status as a goal to achieve. Thus, Agamben slightly tweaks Benjamin's weak messianic force, making this task of clearing all tasks the main act to fulfil in the present time. This latter is the Pauline ho nyn kairós, the time of now, the proper messianic time, which now has to be analysed.

In his description of messianic time, Agamben emphasizes its proper connotation, differentiating it from ordinary present time (the continuous sequence of identical moments, one subsequent to the other), but also from apocalyptical and from eschatological time. While apocalyptic time is the end of time, the very moment - foreseen by the prophets - in which history comes to an end (and in this sense it overlaps with eschatological time as the last time), messianic time must find its place in the very present of the apostolate (Agamben 2000, 63). Thus, messianic time is not a transitional time, between the present and eschatological time, but rather a contraction of the present moment. It is the shrinking of time itself, a recollection of all the moments of the past in a single moment, in so far as the possibilities embedded in past events can be actualised in the now, and in this actualisation find real redemption. Agamben argues in favour of a dialectical representation of time: not present, nor past nor future, but rather a cut or a remainder inside the continuum of time, engendering an intimate disconnection within the fabric of time itself. In this dialectical representation, the messianic event is split into resurrection (the messianic event properly speaking) and Parousia (the second coming of Jesus as accomplishment of messianic time). But Agamben stresses the etymological meaning of Parousia, 
para-ousia i.e. the act of being aside or being present (Agamben 2000a, 70) and therefore overturns the concept of the delayed second coming of Christ - which permeates the entire Christian eschatological tradition, and its history as well (Taubes 2009, 56). Thus the promise of Christ being present is not relegated to a future "age to come" because this latter has already begun thanks to the messianic event of the resurrection: the task of the faithful is no more that of waiting for the realised eschatology at the end of times, but to prepare themselves in the present moment, the inaugurated eschatology (see Hooker 2004; Roberts 2008a, 70).

To characterise the realised eschatology that takes place in the shrinking time of now, Agamben looks at the peculiar movement of recapitulation. In this contraction of time which leads toward the end, each and every thing, profane as well as divine, is taken up again and finds its proper place: a recapitulation ( $\dot{\alpha} v \alpha \kappa \varepsilon \varphi \alpha \lambda \alpha i \omega \sigma 1 \varsigma)$ of the entire past. The totality of all the past moments is in fact necessary for the attainment of the pleroma $(\pi \lambda \eta \dot{\rho} \omega \mu \alpha)$, the fullness of time (Agamben $2000 \mathrm{a}, 75)$, which is the core of the messianic promise. Not a single moment can get lost if the final redemption has to be finally realised: not a single potentiality can be wasted. Paradoxically, however, it is in the act of deactivation and clearing of all tasks, that this potentiality is preserved and even restored to its utter capacity - the possibility not to act. This is done through Agamben's reading of the Pauline notion of katargesis

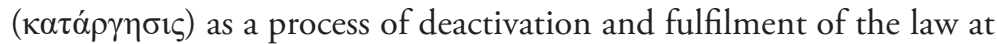

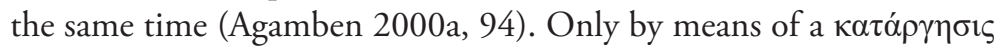
- only by rendering inoperative the law - can the totality of the past possibilities come to actuality and thus contribute to the fullness of time, which encompasses the fulfilment of the law as well; this contribution requires the recapitulation of these past moments and takes place in the present messianic time.

It is finally evident how this latter bears the mark of inoperativity: the accomplishment of the promise of the fullness of all time is realised through the act of suspension and deactivation, realised in the "time that remains". This way Agamben is able to read Paul's "time of now" in terms of an anti-utopian stance, since there is no need to wait for a future world to come, given that after the messianic event - after Christ's resurrection - we entered a time of inaugurated eschatology and therefore, as Salzani observes, "it is in this world, in the present, that we have to uncover the potentialities for the new world, a supplementary world that exists already, in potential" (Salzani 2012, 227). And the "time of now" is anti-utopian in so far as it is anti-teleological, that is, 
it rejects all the ends forcibly assigned to man and frees him as a pure means. The cut of messianic time acts as a suspension of the machine; it does not destroy it but rather renders it inoperative and allows all the possibilities, which in the past have been negated to be finally freely expressed.

Here it also becomes clear the extent to which Benjamin's framework informs Agamben's reading of Paul's messianism. It is precisely in the nexus of past-fulfilment-deactivation that Benjaminian messianic nihilism becomes more evident - and particularly in two points. In first instance, as in Benjamin, in Paul messianic time in fact shows the same two-fold structure - the two faces of the dialectical image, seized in the moment, are directed towards present and past:

The messianic is not a third aeon between two times, it is, rather, a cut that divides the same division of times, introducing a remainder between them, an indifference zone in which the past is dislocated into the present and the present is spread out into the past. (Salzani 2012, 74)

The proper form of the time that remains, the present time, entails a deep connection of present and past. Secondarily, the accomplishment of the messianic promise in the Parousia takes the form of a suspensive practice of which the anomia (the absence or deactivation of the law) is the only possible implementation. In this sense, messianic time is precisely the place where the Pauline principle "hos me" - literally: "as if not" - can be practised. The apostle invites the Corinthians to make use of the world as if they do not use it (1 Corinthians 7:29-31). This is precisely the point where the Benjaminian " $s h w$ a $c$ b e messianische Kraft", turned by Agamben into the essentially inoperative character of humankind, manifests itself in its utmost political meaning. It is not by owning the things of the world but by making use of them that man fulfils his nature: not within a despotic relation of possession, but rather by the free use of things - and of the bodies in first instance - the "coming community" takes place.

To sum up, the messianic cut of present time is realised through a recollection of every single past event in the very present moment. This burden requires a suspension of the laws, a de-legitimation of the current order, and the subsequent opening up of the real state of exception. In other words, in messianic time, located between time and its end, the messianic remainder and its weak force breaks the continuity and evokes the past, making it possible to suspend, deactivate, and make inoperative the devices of law and power. It has to be incidentally noted 
In Agamben's reading, we can find only half of the potentiality of the Pauline principle, only the side of the past. And as a result, we get

the possibility to suspend or deactivate the biopolitical machine but not to go further

in reassembling a subject on the left. that this is not an example of a weak messianicity in the sense of deconstruction: there is no infinite deferment of the attainment of a result. On the contrary, the call for action takes place here and now, but it is a call for subtraction as the proper embodiment of the messianic spirit. In Agamben's reading, we can find only half of the potentiality of the Pauline principle, only the side of the past. And as a result, we get the possibility to suspend or deactivate the biopolitical machine but not to go further in reassembling a subject on the left.

\section{Bloch: Parousia as Future}

Reading Paul as a herald of passive politics, however, is neither the first nor the only option that has been explored by thinkers who placed the messianic wager on the table of radical politics. By turning the attention to Ernst Bloch, this paper will now explore his original reading of the Scripture, showing how he interpreted the Pauline Parousia, recovering the eschatological potential of this notion according to his conception of messianic time.

While in the last twenty years we have witnessed a tightening of the connection between politics and religion, Ernst Bloch could be seen as a forerunner of this tendency. He dealt with religious topics and issues from his early works - and notably in the first edition of Geist der Utopie there were already many chiliastic, messianic and gnostic elements (Münster 1982), which contributed to Bloch's sketch of a rich utopian imagination. But while it is true that in the first three decades of the last century this tendency was shared by a lot of radical thinkers, especially German-Jewish ones (Löwy 1992), it is interesting to note that the influence of religion in Bloch's works remained firm also during the 1950s and the 1960s, after his acquisition of a Marxist standpoint (Hudson 1982). ${ }^{4}$ The importance of religion probably even grew after 1961, when he moved to West Germany, after several conflicts with the orthodox Marxist environment of Leipzig, and after he came into contact with the prolific environment of the Tübingen theologians.

Here he tried to enforce a connection - not to say an alliance between different sources, aimed at similar or even identical political aspirations. The combination of Marxism and Christianity takes shape

4 Cunico (2003) shows how it is possible to detect a materialistic turn in Bloch's production already in 1926; the complete maturation of his Marxism would take place in the 1930s, while working at his Logos der Materie, published posthumously by Cunico himself. 
in the context of Bloch's interpretive inheritance of religious ideas, developed in his Principle of Hope, but it finds its full application only in his late work Atheism in Christianity, written in the Tubingen years and published in 1968. Bloch idiomatically summarised it in this brief but impressive claim:

Implicit in Marxism - as the leap from the Kingdom of Necessity to that of Freedom - there lies the whole so subversive and un-static heritage of the Bible. (Bloch 2009a, 57)

Bloch thinks of a possible fruitful reading of the holy texts in terms of a heritage, which has its own method. This process resembles a precision cutting which goes through the Scripture and produces a division between the regressive material - which must be left aside and firmly denounced and opposed - and a progressive part, which must be inherited. This "cut" is intended as a heretical exegetical work on the text that aims to discover and exhume the

underground Bible, both infra and contra and ultra the heteronomous light of the theocratic firmament; criticism has made investigation of it possible. [And this is the] real Biblia Pauperum, which had the intention, against Baal, of "overthrowing every state of affairs in which man appears to be oppressed, despised and forgotten in his very being”. (Bloch 2009a, 69)

But when it comes to reading the Letters of Saint Paul, Bloch's reading fails to fully acknowledge the potentially progressive elements of Paul's theology. His reading remains informed by the "dominant history of occidental Pauline interpretation, especially after the emperor Constantine set in motion a history that would convert the Roman Empire to Christianity and to conform Christianity to the empire" (Kahl 2010 , 4). As a result, Bloch insistently criticises "Paul's doctrine of sacrificial death" and Paul's allegedly

destructive work; for its aim was to break the subversive element in the Bible once and for all, with the myth of the victim Lamb. It was to be a sanction for the so-called patience of the Cross - so praiseworthy an attitude in the oppressed, so comfortable for the oppressors; a sanction, too, for absolute and unconditional obedience to authority, as coming from God. (Bloch 2009a, 161)

In other words, Bloch charges Paul with having turned every attempt made by a theology of hope to change and modify this world into a conformist and eventual passive attitude, as attested by chapter thirteen 
of the Letter to Romans, where Paul commands: "Let every person be subject to the governing authorities" (Romans 13, 1).

Despite Bloch's harsh - and now perhaps old-fashioned - criticism of the apostle, he is able to pronounce a "yet" and to stress another crucial aspect of Pauline theology. In fact, Bloch acknowledges that the announcement of the resurrection unveils a potent image of incorruptibility, through the idea of Baptism in the death of Christ (Bloch 2009a, 161-62). This idea, namely that we who have died in Adam, will be made alive in Christ, reveals for Bloch a kind of gateway through death, which in Bloch's philosophy is deemed to be the anti-utopia par excellence. The announcement of the resurrection event proclaimed by the apostle conveys the first joyful wish-mysterium, "unempirical and speculative", as Bloch puts it.

To describe the role played by this powerful image, Bloch uses the term Leitbild, a guiding-image (Bloch 1996a, 3:930-34). This is a figuration, aesthetic or religious, aimed to indicate the ultimate goal, to set (and maintain) the right direction and to inspire hope and courage for action. Bloch describes its function as follows:

Paul's doctrine about Christ, based on an anti-death mystique [...] was in effect an effective force against the phobia of nihilism, which had just then begun to show itself in late antiquity. It was a Tribune of humanity, sent out against the hardest of all forms of anti-Utopianism that we encounter in our present supremely heteronomous world: sent out in the face of death. (Bloch 2009a, 162)

Together with the resurrection, there are two other wish mysteries, both drawn from Paul's Letters: the Ascension and the Parousia. The meaning of the Ascension has to be found on the basis of the movement made by Christ. Bloch reads this rising up from a terrestrial place into heavens as a representation of an irruption or bursting into the on-high (Bloch 2009a, 162). Thus, this movement conveys the sense of a usurpation, committed by Jesus, the son of man, against the Lord, and now the private sanctuary of God has been transformed into the heavenly Jerusalem by Jesus as the liberator of people.

The third mystery is the Parousia. Bloch does not distance himself from the traditional interpretation of this mystery as the Second Coming of Jesus, a Return after the ascension: he, the son of man or the Lord who rejected Lordship, was not only expected to dare the Heavens but also to come back. And in this return Jesus is acting as the Avenger. In fact, he is the redeemer and comes back to bring redemption, but the Hebraic word for redemption is Go'el, the primary meaning of which 
refers to the closest relative and heir of a murdered person, who has the duty to avenge their death (Bloch 2009a, 100). In Bloch's words:

He appears now, however, more as the Avenger of Job as the preacher of the Sermon on the mount. Only for the labourers and heavy-laden, the degraded and despised, will the Second Coming be a mild one: only for those who are more than prepared for it. (Bloch 2009a, 166)

According to Bloch, the Parousia has a triple meaning. In first instance, it is no more than a mere reversal: the lowly will be exalted and the mighty brought low - so the old power structure is maintained and the only difference is that instead of the ancient Lord now we find the heavenly power of Christ, son of God. But beyond this a second meaning appears: Christ's love for the oppressed is the counterpart of the justice invoked for the evil-doers and salvation for those who have been liberated. In this way the old despotic order is wiped out by the return, and only love describes the relationship within the community. Here the third and most important meaning of the Parousia is revealed, as it is indicated in the book of the Apocalypse. In this setting, the Return concerns the anthropocentric image of the heavenly Jerusalem - a utopian image - which was to come down to men. The striking point in this depiction, according to Bloch, is that of a city in which the human and messianic figure of Jesus has taken over the old image of God, master of the worlds of sun and moon, as if to say that the human world, made by horizontal relations within the community, has taken the place of the vertical submission of the world to the ruling power of God - or of the King, his delegate. In this way the Parousia is not just a mystery juxtaposed to the other two, but it determines their final accomplishment. If the resurrection shines a light in the darkness of death and ascension represents man daring to usurp the Heavens, only in the return - the final realisation of the city of man - is all this tension finally released.

The focus on the mystery of return within the economy of the book is mainly aimed at supporting one of Bloch's key arguments, namely that the prime and most noteworthy title of Christ is "son of man", instead of the later and cultic title of "son of God", to which much of the developments of the history of the church is related - the church of the Lords, of course. The Parousia, the second coming of Christ, here serves to debunk this reading by presenting an anthropocentric - and thus anti-despotic - image of the city to come, illuminated by the Lamb. Nonetheless, it must be noted that it is not an accident that the doctrine 
of the second coming, the synthesis and peak of the progressive elements of the wish-mysteries - and so the bulk of the religious heritage - has its place in future time: this has much to do with the Blochian account of messianic temporality. In fact, the Parousia must be waited for, invoked, and prepared.

\section{Bloch's eschatology}

Understanding the Parousia as the Second Coming, Bloch, unlike Agamben, stresses the eschatological and apocalyptic load of this potent image, placing it in a future, desirable time. Messianic time is for Bloch tightly intertwined with the apocalyptic, and therefore stretched towards the future possibility of a "meta-history", the locus of the "New Jerusalem at the 'end of time" (Bloch 1975, 96). This cryptic passage from Experimentum Mundi, his last published work, is not the only one where Bloch tries to describe the ultimate future time in which the realisation of utopia has to find its place. However, the presence of an eschatological tension inside the Blochian philosophy should not mislead us when analysing his account of temporality.

There are several passages in Bloch's early works, especially the Spirit of Utopia, where the eschatological tension generated by the future utopian world is intensified to the vision of a global catastrophe involving all humanity and its world (see inter alia Bloch 2009b, 197). In this context, the eschatological focus seems to make the apocalyptic event take on the meaning of the end of history, or at least the end of the current aeon - along with all its worldly features. It is easy to see that this is a deeply problematic representation of the eschaton, since it is not clear when it is supposed to happen, under what conditions, and how this great event of apokatastasis is envisioned.

In a different reading, the eschaton could be interpreted as a Grenzbegriff, a limit-concept, or as a Kantian regulative idea, thus transforming it into the telos of a traditional teleology (see Mendes-Flohr 1983, 644). In so doing the final event is rethought as a final aim towards which people should orientate themselves throughout their historical journey, but without ever touching this ultimate goal. In this view, the movement and action of humanity in history is destined to be a game structured as an infinite progress, lacking any concrete satisfying prize to grasp.

Within the traditional conception of eschatology only a fixed teleology is possible: the final goal is given in advance and history becomes 
the process of longing for it. This framework entails an essentialist conception of the eschaton, where it is already defined at the very beginning of the historical process. Thus, the final aim for which humankind strives is pictured as a pre-determined ideal, either ungraspable (a limit concept which leads the progressive path of history) or seizable in a structured organisation of society and human relations. In other words, this eschaton is an essence whose attributes are already given, and the moment in which it comes to existence is nothing but a fact which takes place (or is only awaited) at a certain point in history. This essence can belong as much to a determinate kind of perfect society as to a determined development of human capabilities. A philosophy of history of this kind can only be paired with a close system of thought which risks on the one hand leading to a totalitarian political system - the only one that conforms to that utopic ideal - and, on the other, allowing the reproduction of biopolitical power over people in a disguised form of democracy that claims to pursue that ideal itself. In both cases, the eschaton acts as the central gear of the theological-political machine.

Rather than thinking of the eschatological element as a fact or as an essence - which is either to be found at the end of history or in the intelligible world of regulative ideas - I argue that it is possible to interpret it as a function. And this function operates not from outside history, attracting it to a pre-formed end-goal or determining its catastrophic end, but from inside history, and precisely in the very core of it: the present moment, the Augenblick. This moment, albeit similar to the Jetztzeit of Benjamin and Agamben, is indeed only the beginning of a wider present moment: it is through the mediation with the current tendencies that this punctual and instantaneous moment is expanded into the "temporal work-field of the front of the process" (Mendes-Flohr $1983,87)$. And the peculiarity of such a moment is that it is stretched towards the future, rather than recollecting the past. In The Principle of Hope the Augenblick is described as bi-facial, with one side directed to the very present instant, when the impulse to escape from a deprived situation leads towards a decision and to action, and the other side points to the future, the "Ultimum of the content" (Bloch 1996b, 298), as Bloch puts it. In other words,

Every lived moment would therefore, if it had eyes, be a witness of the beginning of the world which begins in it time and time again; every moment, when it has not emerged, is in the year zero of the beginning of the world. The beginning occurs in it time and time again for as long as it takes until the undefined Not of the That-ground is decided, through the experimental definitions of the world- 
-process and its forms, either as definite Nothing or definite All, according to its content; every moment therefore likewise potentially contains the date of the completion of the world and the data of its content. (Bloch 1996b, 308)

And even more explicitly: "That which is at work within it [the moment], after it has emerged from its immediacy, finds itself and everything at first as future" (Bloch 1975, 90)..$^{5}$ These two sides - mediated present and ultimate future - are inseparable and together build up the elementary unity of the Blochian account of temporality. Insofar as the Parousia, the Second Coming awaited at the eschaton, is placed in a desired ultimate future, this wish-mystery performs its proper function precisely inside the Augenblick, at the core of the present. The last times, the end of history, from this new standpoint, take on a different "location": they act inside the lived moment, where through their specific weight they play their role of orienting the present decision towards the intentioned direction.

No matter what essence or fact can be implied in the image of the Parousia, it is possible to approach and inherit this Pauline doctrine as an intra-historical operator. In fact, despite its depiction of a distant future time, it fulfils its function in the most advanced section of human history, at its front, right inside the moment in which the decision is taken to fight for a possible better world. And its function is precisely that of averting the closure of the system, which is to say preventing a provisional outcome, gained during the process, from being traded for the ultimate goal. In brief, forbidding a reification of any achieved result. The eschatological function in Bloch is thus not a mere operation which from an input produces an output, but rather an element that, according to its etymology (from Latin: functionem, fungere), acts, operates, works. It instils a teleological tension in the historical process, but thinking the telos of a non-fixed teleology, i.e. a telos which can be continually rearranged and freely modified throughout the process, through "experimental definitions" of its form and content. This is the utopian role of the ultimate goal - and the Parousia image is its harbinger.

\section{Mediation}

In the Blochian structure of messianic time, therefore, the present moment keeps its crucial role, being indeed at the core of the pulsating

5 „Das in ihm Treibende findet, nachdem es als seinem Unmittelbaren herausgetreten ist, sich und alles zuerst als Zukunft“. 
subject who enacts the transformation of the real. In this sense, messianic time can be described as the intimate disconnection of the fabric of time, an exceptional time that allows us to exit the stream of ordinary, mundane historical events - in this regard Bloch is very similar to what we find in Agamben. But where the Pauline Kairós for Agamben is the moment of the recapitulation of the past, for Bloch it is the instant of the future-oriented decision. Instead of a recollection of past events which can be redeemed in every single moment, Bloch insists on the liberation of the "future embedded in the past", of the Spannung, the tension accumulated in the past (Bloch 1975, 92). While for Agamben, who follows Benjamin in this aspect, the totality of the past comes to be suddenly redeemed in the present instant, Bloch's decision operates a cut through the past and unlocks only the progressive content which has not yet been expressed, discarding the crust (i.e.: social and political institutions) that trapped it. Where Agamben stresses the suspension of the current system(s) of domination, Bloch highlights the possibility to awaken and stir the forces which, although paralysed by previous events, are still enclosed in the pattern of history.

In the closed historical-material process, this embedded content exerts a pressure in the direction of progressive development - or, in Bloch's terms, a Tendenz towards the ultimate goal - that opens a window in the historical process into its exceedance. But, again, this extra-historical plan must not be thought of as a supersensible ulteriority, which would be a mere fictional duplication of reality, nor a completely other epoch, which would be only a repetition of this time. Rather, it refers to a peculiar modality of human behaviour, which has to be adopted in order to pursue the social and political goal of a renovated world. "Staying in history as if we did not" (De Martino 2015) - this is probably the best motto to describe such a mode of behaviour: determining, in every Augenblick, the discrepancy between what there is and what there should be. Here the Pauline motto hos me as the proper approach to the messianic time emerges again. But in this case, contrary to Agamben, the extra-historical positioning allowed by messianic time does not entail the suspensive or deactivating character of political action. Rather than a subtractive practice, Bloch suggests an even more engaged commitment towards the current political situation.

In regard to what can be called with Roberts "a position of 'weakness' and disengagement" (Roberts 2008, 95), adopting a Blochian perspective would entail a readjustment of the Pauline hos me: the latter would take the meaning of acting in a non-identitarian or non-essentialistic way within the current political structures. Mediation, taken in this
Where Agamben stresses the suspension of the current system(s) of domination, Bloch highlights the possibility to awaken and stir the forces which, although paralysed by previous events, are still enclosed in the pattern of history. 
meaning, is not an act opposite to that of subtraction. However, while this latter consists in a withdrawal from reality in search for a real conceived as a gap, a fracture or a tear in the impervious social fabric, mediation thinks of the real as a force capable of trickling forth through the inevitably porous fabric of reality. As a result, mediation calls for bursting in and subverting from inside the legal, gender, ethnic, etc. structures, rather than sneaking outside of them and acting in a supposed suspension of their hegemony, as subtractive politics too often risks hinting at. The movement of mediation can be thus seen as a slight correction or necessary complement to that of subtraction: without renouncing the entelechy, without abdicating to the imagination of the (utopian) goal of restructuring the social and political environment, but thinking its predicates in a non-teleological way, always kept open to further rearrangements - in short, thinking its being as not-yet-being. Only in this way is it possible to conceive of the Parousia not only as something that has to be awaited, but also as an event that we are actively preparing.

Yet what is Parousia but the potent image in which ancient Christians had faith? It is clearly not the same Leitbild, that which can be effective today, since the image of a divine saviour effectively acting in history does not attract believers as it used to. Nonetheless the hope for the second coming - the wait for a redemption which leads to a future better world - can still be theological-politically relevant, if we are able to detect the same systematic structure that lays behind a religious principle and its secularised counterpart. At the same time, a new image has to be found - an image which is clear, potent and reminds us what humanity is and what is not. It is perhaps to the touching image of a refugee who was saved from drowning in the Mediterranean Sea, or to the persecuted stranger defended from racist attacks in the outskirts of our cities that we can turn our sight. Though not directly religiously connotated, both these glimpses carry the unprovable truth - an axiom of truth, in Badiou's words - that only a theological principle could sustain. What is active in these images is a postulate of a practical ethics. Bloch uses the term "radical natural law" to indicate this set of postulates anchored on an unconstructable core of a "real human dignity" (Bloch 1986, chapter 22): a moral axiom whose Marxian claim reads "From each according to his ability, to each according to his needs". Besides that, if the mediation with the harsh reality of our social structures does not want to be transformed in connivance or even complicity with them, the ethical flag of the primacy of the other has to be raised at any 
instance. The phagocytising reality that does not stop subsuming the subject under the over-ordained fixed set of concepts can be only resisted by appealing to the other as the unconceivable, the incomprehensible: a constant monition against a system casting on the subject its norms, rules, divisions, identities.

Acting within these structures in the attempt to find mediation with this reality requires a radical ethical subversion of categories, lest this mediation becomes just another act of reproduction of the current system. That human beings are intrinsically worthy of their lives, that it is our task to preserve their dignity and made it flourish; but also and foremost that the other (the underprivileged, the marginalised, the periphery - no matter whether that of the city or that of the world) comes before myself - even before my understanding of them - and that it is my duty to help them: these are the postulates whose systematic structure can be turned into a laic and even materialistic ethics. To repeat after Benjamin, these are the secret moves of the "little hunchback who was an expert chess player" - of theology - that can make the "puppet in Turkish attire" - materialism - win the game (see Benjamin 2007, 253). The primacy of the other and the indelible dignity of man - these two theological principles - could be the Parousia of the current times. The saviour is no longer a supernatural entity that comes from above, it is rather man himself, but nonetheless moved by these two ethical postulates, exceeding history as its ultimate ideal and still acting eminently within history. Lifting the flag of human dignity within the social and political environment leads to the construction of solidarity (Bloch 1986, chap. 22), informed by equality and the end of oppression. This is how eschatology as a function is performed as mediation with the real, as commitment to actual needs - and it is perhaps from here that the search for the sufficient condition of an answer to the impelling political demands could start; from here it is perhaps possible to re-think political subjectivity. The mobilisation of this ethical imaginary of solidarity shows the power of the eschatological element. The extra-historical messianic element - the primacy of the other and the absolute dignity of man - albeit exceeding the continuum of time, since it is referred to the fulfilment of time, still acts and operates within the stream of history, ethically and politically re-orienting its course.

This ethical imaginary, which shows the ultimate political goal can be subsumed under what Bloch calls the "warm stream" of Marxism and its mediation with the historical process, is what distinguishes Blochian messianic temporality from that of Agamben. The proper meaning of

The extra-historical messianic element the primacy of the other and the absolute dignity of man - albeit exceeding the continuum of time, since it is referred to the fulfilment of time, still acts and operates within the stream of history, ethically and politically re-orienting its course. 
this mediation has to be looked for inside the Blochian distinction between, and interconnection of, the warm stream and the cold stream in Marxism, so described in his magnum opus:

The conditional analysis of the whole historical-situational stretch emerges both as an unmasking of ideologies and as a disenchantment of the metaphysical illusions; precisely this belongs to the most useful cold stream of Marxism. [...] To the warm stream of Marxism, however, belong liberating intention and materialistically humane, humanely materialistic real tendency, towards whose goal all these disenchantments are undertaken. (Bloch 1996b, 1:209)

These two streams are deeply interdependent, the one being the way to follow, the other the goal to achieve. Their point of connection is that in which the eschatological function operates. It is thanks to the warm stream that the goal of human solidarity can be conceived as telos (one of a non-fixed teleology) that exerts its power in continually modifying and re-defining the course of history.

To sum up, it is the task of the warm stream of Marxism to individuate an accessible image of the ultimate goal, rather than abdicating to any political end, lest it could lead to an identitarian conception of politics unable to escape the seizure of the biopolitical machine. This image has nonetheless to be indeterminate, its telos has to be still in fieri, not pre-defined or given in advance; solidarity and emancipation are by definition achievable via an imposed process. This not-yet defined, not-yet fulfilled eschaton is the lynchpin of mediation, since it bridges the gap between the extra-historical and the intra-historical dimensions. And this operation takes place in the very moment when history itself is forged, in the now of the decision. As in Agamben, messianic time is the present, but for Bloch the present is the time of mediation, not of subtraction. With his words: "The moment [Augenblick] - which for everyone else constitutes a conceptual embarrassment - is raised here to the time of decision, in the perspective of a Totality" (Bloch 1985, 600). It is worth stressing that the Augenblick here is not an isolated instant, a flickering flash in the darkness of time, but rather the re-activation of a process, an extra thrust towards the pre-figured but always provisional aim - the "Totality" of justice and equality. This is messianic time: the time of decision, a mediation that takes place in the here and now, but clung to the perspective of totality, i.e. with the picture of the ultimate goal as a leading-image, with the new Parousia of solidarity. The exceedance of history which acts within history itself. 


\section{Conclusion}

Within the horizon of the current crisis of political subjectivity, the hard task of reinvigorating and rebuilding a Marxist subjectivity, while in the meantime rejecting the paradigms of the twentieth century - party, class, state - is often assigned to messianic or, more widely, to political theology (Vatter 2017). Still, it is not clear what the extent and the limitations of such an approach are. It could be true that today the political left is struggling to find an organisation and a structure fit for itself, but perhaps the gesture of subtraction of political subjectivity can be stopped short of becoming total itself. In so far as the commitment to the underprivileged, the marginalised and the oppressed is still present at the core of the left, by addressing their need, the messianic as the powerful spirit of the warm stream can help to tear the veil of necessity and provide them with the hope for a possible transformation. And in this relationship, turning our attention to those whom history has forgotten, it is perhaps possible to win back the populist party consensus now almost entirely monopolised by the far-right. The cold stream, on the other hand, calls for a re-thinking of macroeconomics, debunking its myths and understanding the soft powers, showing the limits and the paradoxes of the current economic-political systems. Any kind of organisation needs achievable goals - no matter how provisional - to provide feasibility for any project of an alternative socio-political structure. The way to the solution of the problem of subjectivity for the left passes through this care for the least and this attention to the actual economic situation. Bloch's future-oriented utopia and his call for engagement may be its milestones.

\section{References}

Agamben, Giorgio. 2000a. Il tempo che resta: un commento alla Lettera ai Romani. Torino: Bollati Boringhieri.

. 2000b. Means without End: Notes on Politics. Translated by

Vincenzo Binetti and Cesare Casarino. Minneapolis, Minn.-London:

University of Minnesota Press.

- 2003. The Coming Community. Translated by Michael Hardt. Minneapolis, Minn.-London: University of Minnesota Press.

Badiou, Alain. 2003. Saint Paul: The Foundation of Universalism. Trans- 
lated by Ray Brassier. Stanford, Calif.: Stanford University Press.

- 2004. Theoretical Writings. Edited by Ray Brassier and Alberto

Toscano. London: Continuum International Pub. Group.

- 2007. "Destruction, Negation, Subtraction - on Pier Paolo

Pasolini”. Graduate Seminar Transcript, Art Center College of Design in Pasadena. https://www.lacan.com/badpas.htm.

Benjamin, Walter. 2007. "Theses on the Philosophy of History”. In Illuminations: Essays and Reflections, edited by Leon Wieseltier, translated by Harry Zohn, 9th ed., 253-64. New York: Schocken Books. 1998. The origin of German tragic drama. Translated by John Osborne. London: Verso.

1999. The Arcades Project. Translated by Howard Eiland \&

Kevin McLaughlin, Cambridge, Mass.-London: Belknap Press.

Bloch, Ernst. 1975. Experimentum mundi: Frage, Kategorien des Herausbringens, Praxis. Frankfurt am Main: Suhrkamp.

—. 1985. Philosophische Aufsätze zur objektiven Phantasie. Frankfurt am Main: Suhrkamp.

- 1986. Natural Law and Human Dignity. Translated by Dennis J. Schmidt. Cambridge, Mass.: MIT Press.

- 1996a. The Principle of Hope. Translated by Neville Plaice, Stephen Plaice, and Paul Knight. Vol. 3. Cambridge, Mass.: MIT Press.

1996b. The Principle of Hope. Translated by Neville Plaice, Stephen Plaice, and Paul Knight. Vol. 1. Cambridge, Mass.: MIT Press.

- 2009a. Atheism in Christianity: The Religion of the Exodus and the Kingdom. Translated by J. T Swann. London-New York: Verso. 2009b. The Spirit of Utopia. Translated by Anthony A. Nassar. Stanford, Calif.: Stanford University Press.

Borsò, Vittoria, Claas Morgenrooth, Karl Solibakke, and Bernd Witte, eds. 2010. Benjamin - Agamben: Politik, Messianismus, Kabbala. Würzburg: Königshausen \& Neumann.

Chattopadhyay, Arka. 2011. "Alain Badiou's Truth-Ful Politics of Subtraction and Genericity". In Avenel Companion to Modern Social Theorists. Burdwan: Avenel Press.

Cunico, Gerardo. 2003. "Logica utopica. Logos der Materie tra sistema e narrazione". In Ereditare e sperare: un confronto con il pensiero di Ernst Bloch, edited Patrizia Cipolletta, 55-70. Milano: Mimesis.

De Martino, Ernesto. 2015. Magic: A Theory from the South. Edited by Dorothy Louise Zinn.

Deuber-Mankowsky, Astrid. 2008. “The Image of Happiness We Har- 
bor: The Messianic Power of Weakness in Cohen, Benjamin, and Paul". New German Critique, no. 105: 57-69.

Franchi, Stefano. 2004. "Passive Politics". Contretemps: An Online Journal of Philosophy, no. 5: 30-41.

Frick, Peter, ed. 2013. Paul in the Grip of the Philosophers: The Apostle and Contemporary Continental Philosophy. Minneapolis, Minn.: Augsburg Fortress Publishers.

Georgi, Dieter. 1964. Die Gegner des Paulus im 2. Korintherbrief. Studien zur religiösen Propaganda in der Spätantike. Neukirchen-Vluyn: Neunkirchener Verlag.

Hallward, Peter. 2003. Badiou: A Subject to Truth. Minneapolis, Minn.-London: University of Minnesota Press.

Hamacher, Werner. 2001. “NOW': Walter Benjamin on Historical Time”. In The Moment: Time and Rupture in Modern Thought, edited by Heidrun Friese, 161-96. Liverpool: Liverpool University Press.

Heiden, Gert-Jan van der, Geurt Hendrik van Kooten, and Antonio Cimino, eds. 2019. Saint Paul and Philosophy: The Consonance of Ancient and Modern Thought. Berlin: De Gruyter.

Hooker, Morna Dorothy. 2004. Paul: A Short Introduction. Oxford: Oneworld.

Horsley, Richard A. 1997. Paul and Empire: Religion and Power in Roman Imperial Society. Harrisburg, Pa.: Trinity Press International.

Hudson, Wayne. 1982. The Marxist Philosophy of Ernst Bloch. London: Palgrave Macmillan.

Kahl, Brigitte. 2010. Galatians Re-Imagined: Reading with the Eyes of the Vanquished. Minneapolis, MN: Fortress Press.

Khatib, Sami. 2013. "The Messianic Without Messianism. Walter Benjamin's Materialist Theology”. Anthropology \& Materialism. A Journal of Social Research (Online), no. 1 (October). https://doi.org/10.4000/ am.159.

Löwy, Michael. 1992. Redemption and Utopia: Jewish Libertarian Thought in Central Europe: A Study in Elective Affinity. Translated by Heaney Hope. London: Athlone.

Martel, James. 2011. “Taking Benjamin Seriously as a Political Thinker". Philosophy \& Rhetoric, no. 44 (4): 297-308. https://doi.org/10.5325/ philrhet.44.4.0297.

Mendes-Flohr, Paul R. 1983. “'To Brush History against the Grain’: The Eschatology of the Frankfurt School and Ernst Bloch”. Journal of the American Academy of Religion, no. 51 (4): 631-50.

Münster, Arno. 1982. Utopie, Messianismus und Apokalypse im Frühwerk von Ernst Bloch. Frankfurt am Main: Suhrkamp. 
Prozorov, Sergei. 2014. Agamben and Politics: A Critical Introduction. Thinking Politics. Edinburgh: Edinburgh University Press.

Roberts, John. 2008a. "The 'Returns to Religion': Messianism, Christianity and the Revolutionary Tradition. Part I: 'Wakefulness to the Future'”. Historical Materialism, no. 16 (2): 59-84.

- 2008b. "The 'Returns to Religion': Messianism, Christianity and the Revolutionary Tradition. Part II: The Pauline Tradition". Historical Materialism, no. 16 (3): 77-103.

Salzani, Carlo. 2012. "Quodlibet: Giorgio Agamben's Anti-Utopia". Utopian Studies, no. 23 (1): 212-37.

Taubes, Jacob. 2004. The Political Theology of Paul. Translated by Dana Hollander. Stanford, Calif.: Stanford University Press.

- 2009. Occidental Eschatology. Stanford, Calif:: Stanford University Press.

Tronti, Mario. 2019. Workers and Capital. London-New York: Verso.

Vatter, Miguel. 2017. "Community, Life and Subjectivity in Italian Biopolitics". In The Routledge Handbook of Biopolitics, edited by Sergei Prozorov and Simona Rentea, 123-39. Farnham, Surrey: Ashgate. Walzer, Michael. 1985. Exodus and Revolution. New York: Basic.

Žižek, Slavoj. 2000. The Fragile Absolute, or, Why Is the Christian Legacy Worth Fighting For? London: Verso. 
FEDERICO FILAURI - is currently a PhD student at the School of Advanced Study, University of London, where he is supported by a LAHP scholarship. His research project focuses on Jewish and messianic elements in Bloch's thought and engages with problems pertaining to political theology and secularization.

\section{Address:}

Ernst Bloch Centre for German Thought - IMLR

School of Advanced Study

University of London

Senate House, Malet St, Bloomsbury, London

WC1E $7 \mathrm{HU}$

email: federico.filauri@postgrad.sas.ac.uk

ORCID: https://orcid.org/0000-0001-8128-1155

Citation: Filauri, Federico. 2020. "The Mystery of Return: Agamben and Bloch on St. Paul's Parousia and Messianic Temporality". Praktyka Teoretyczna 1 (35): 121-147.

DOI: $10.14746 / p r t 2020.1 .7$

\section{Autor: Federico Filauri}

Tytuł: Tajemnica Powrotu: Agamben i Bloch o Paruzji św. Pawła i czasie mesjańskim Abstrakt: W ciągu ostatnich dwóch dziesięcioleci nowe, radykalne odczytania listów św. Pawła pozwoliły licznym myślicielom zawrzeć w ich filozofii politycznej mesjanistyczny element. W odczytaniach tych mesjanistyczne odrzucenie świata i jego praw jest rozumiane poprzez zawieszający akt ,subtrakcji” - ruch wycofania, którego przekład na polityczną praktykę zbyt często jednak okazywał się nieskuteczny.

Po przeanalizowaniu Agambenowskiej interpretacji subtrakcji przez pryzmat „nieoperacyjności”, artykuł koncentruje się na pojęciu Paruzji jako elementu kluczowego dla zrozumienia jego antyutopijnego ujęcia mesjańskiego czasu. W przeciwieństwie do odczytania Agambena, Blochowska intepretacja Pawłowej Paruzji przedstawia wydarzenie mesjańskie jako wewnątrzhistoryczne, ale równocześnie otwarte wobec celów ostatecznych (metahistorycznych). Jak przekonuję, mesjańskie wezwanie Blocha przyjmuje formę zapośredniczenia, skorygowania subtrakcji tak, by umożliwiała większe zaangażowanie polityczne. W zakończeniu tekstu sugeruję, że konkretne zastosowania tego zapośredniczenia pełnią swą funkcję emancypacyjną tylko o tyle, o ile przyjmują charakter praktycznej etyki, w której uwaga skierowana jest na nieuprzywilejowanych i marginalizowanych.

Słowa kluczowe: czas mesjański, paruzja, subtrakcja, Bloch, Agamben 